\title{
Urban Expansion and Industrial Nature: A Political Ecology of Toronto's Port Industrial District
}

\author{
GENE DESFOR and LUCIAN VESALON
}

\begin{abstract}
This article analyses political and economic practices involved with the production of an industrial form of socio-nature - the Port Industrial District - during the early decades of the twentieth century in Toronto, Canada. Informed by historical documents from that period, as well as using contemporary concepts from urban theory, we analyse the creation of a major land mass and southern extension of Toronto within a political ecology framework. We explicitly link the concept of socio-nature with the dynamics suggested by theories of capital and spatial expansion, thereby bringing 'nature' into a more central position in understanding urban development processes. The Toronto Harbour Commissioners, the central organization in this land-creation process, reflected, we argue, more the ideological preferences and economic interests of local elites than an efficient institutional design for solving a multi-dimensional 'waterfront problem'. The harbour commission and its supporters envisioned and promoted the new industrial district, the pivotal section of its 1912 waterfront development plan, as a general strategy for intensifying industrialization and growth of the city. The massive infrastructure project is best understood as a spatio-temporal fix to productively absorb capital through spatial expansion and temporal deferment. A new institutional arrangement consolidated political and economic relations through practices that made possible the production of a new form of socio-nature and reshaped the eastern section of Toronto's central waterfront as an industrial landscape.
\end{abstract}

Lake Ontario, whether liquid or solid, has always been reckoned among the assets of Toronto (John Ross Robertson in Kyte, 1910: 271)

\section{Introduction}

This article explores how a specific form of socio-nature, urban industrial land, was produced through highly interwoven human and non-human processes that operated on a multiplicity of scales. Our focus is on political and economic practices that transformed a marsh and shallow bay on Toronto's waterfront into urban land during an early twentieth-century period of growth. It is not, however, a study of transportation and utility networks transforming non-urban land into an intense transactional space of urban land. Rather, we focus on social practices by which solid land was physically created.

We thank Jennefer Laidley for her very constructive comments on drafts of this article. Scott Prudham contributed to our ideas on improvement of nature. The Canada Social Sciences and Humanities Research Council supported our work through research grant number 410-2005-2071. 
Though land is frequently considered to be a fixed and non-reproducible asset, our study reveals that land creation was an important aspect of waterfront expansion, in particular, and urban development, more generally.

The approach we use in our investigations is informed by recent work in urban political ecology. In the last few decades, a growing literature, both theoretical and empirical, has appeared that has contributed significantly to our understanding of relationships between nature and society at the urban scale (see Castree, 1995; Castree and Braun, 2001; Keil, 2003; 2005; Heynen and Swyngedouw, 2003; Swyngedouw, 2004; Heynen et al., 2006). We refer to a specific aspect of the political ecology literature that stresses the role of capitalist economic relations in shaping both social and physical processes in the production and reproduction of new forms of socio-nature in cities. Socio-nature, a central concept in the article, is an apparently contradictory term concerned with attempts to unite what the enlightenment and modernity set asunder that is, the assumption that society and nature are separate and discrete entities. This notion has been the focus of a widespread scholarly and activist movement devoted to overcoming the objectification, externalization and commodification of nature (see, for example, Smith, 1984; Haraway, 1991; Latour, 1993; Demeritt, 1996; Harvey, 1996; Swyngedouw, 1996; Gandy, 2002; Whatmore, 2002; Bunce and Desfor, 2007). This body of work looks to surmount the deep ontological and epistemological divide that justified the application of scientific laws and economic interests to an external nature in the production of built environments. Fundamental to this work, and to the approach of our article, is the notion that socio-nature is inherently political because it is, at least partially, produced through social practices and underpinned by political decisions. Introducing the concept of socio-nature into our analysis enables us to discuss how political and economic interests, their discursive representations of nature, and urban development processes are intertwined in the production of industrial nature in the form of 'new' land made available for development.

We explicitly link the concept of socio-nature with the dynamics suggested by theories of capital and spatial expansion, thereby bringing 'nature' into a more central position in understanding urban development processes. Although the study of the commodification of nature under the new regimes of global capitalist accumulation has received significant attention, specific cases of the transformation of socio-nature resulting from the circulation of capital are generally overlooked or less discussed in the existing literature. In an attempt to fill this gap, we use the concept of socio-nature in parallel with Harvey's concept of spatial and temporal fix in order to understand better the connections between capital accumulation and the regulated transformation of socionature. Before entering a discussion of these concepts, we introduce the geographical, temporal and institutional dimensions in the article.

Our specific geographical focus is the eastern section of Toronto's central waterfront where Ashbridge's Bay, an extensive marsh and shallow bay, once existed and on the mouth of the Don River, which fed into and helped create this marsh (Figures 1 and 2). This area has long been an important part of the urban ecology of the region. Ennest Thompson Seton, a prominent early twentieth-century naturalist, wrote about the Toronto Marshes as a special place where different experiences and actors came in contact: a place which attracted birdwatchers, naturalists and artists, as well as hunters and fishermen due to its biodiversity. Seton's (1940) narrative about Ashbridge's Bay offers a valuable perspective on the ways social relations were displaced by industrialization and waterfront development.

The work of Seton also notes that Ashbridge's Bay was of fundamental importance for its ecology and biodiversity, a common element in early accounts of the bay. For example, at the beginning of the nineteenth century when Western European immigration had become dominant, settlers 'saw ducks so thick that when rising from the marsh they made a noise like thunder' (Barnett, 1971: 25). Later in the nineteenth century, Ashbridge's Bay was still important for observing, recording and classifying rare birds (Seton, 1940). Seton even noted that 'at least half the [bird] species known in Canada' 


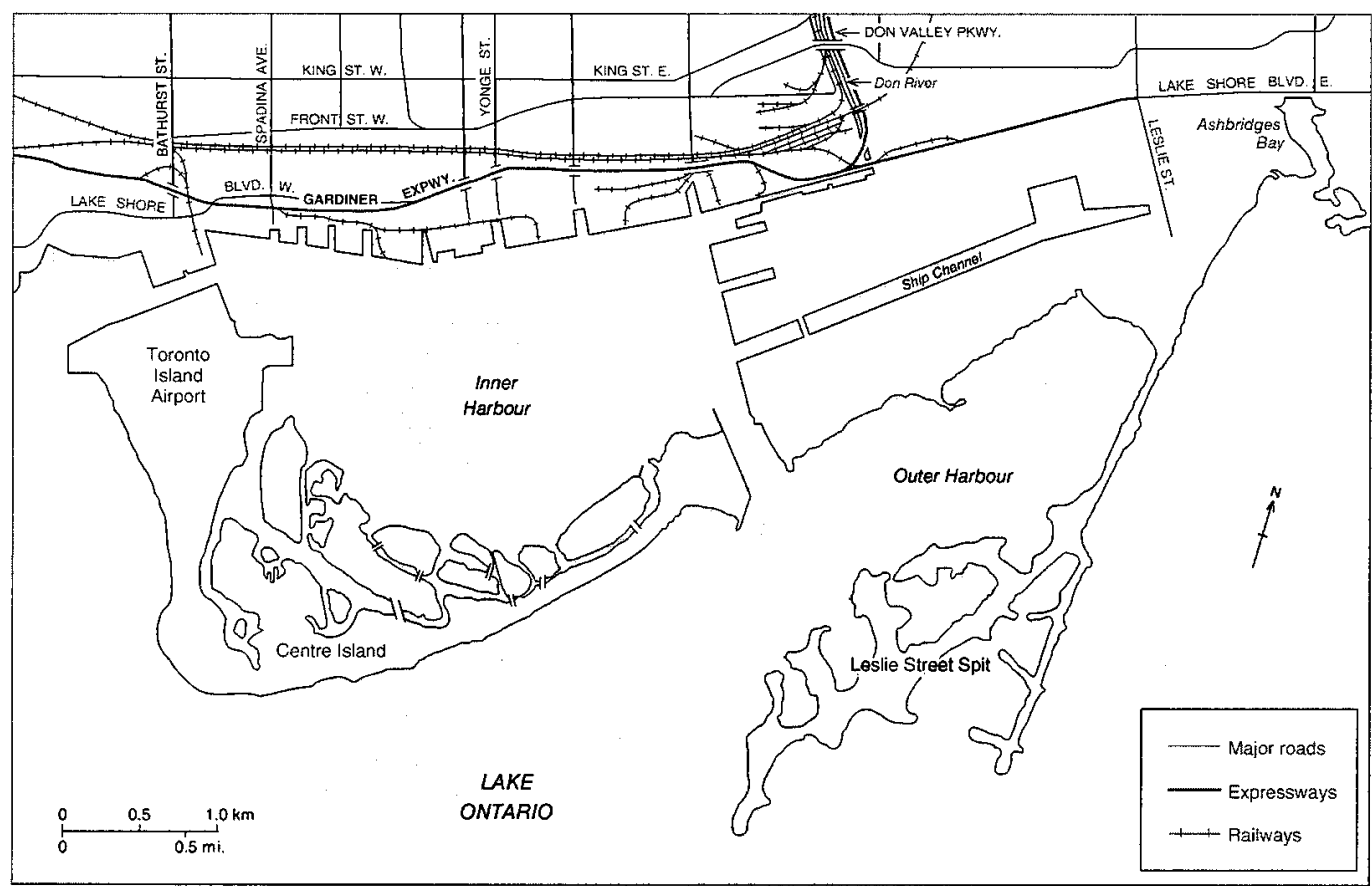

Figure 1 Toronto's Central Waterfront and Harbour

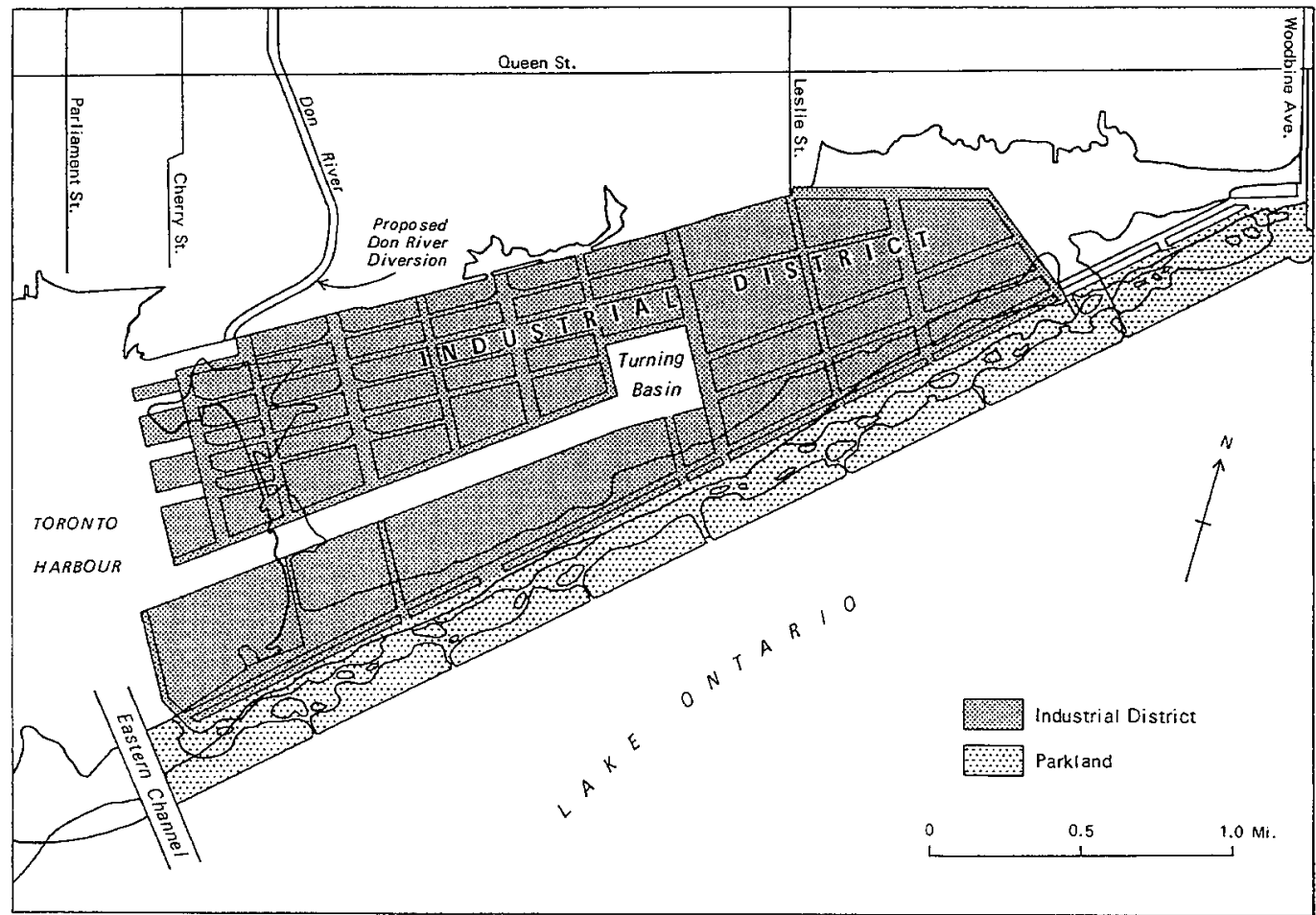

Figure 2 Toronto Harbour Commission's 1912 plan for the Eastern Section of Toronto Waterfront 
could be found in the Toronto Marshes (Seton, 1940: 89). But as Toronto's population and manufacturing increased, the marsh became more renowned as a foul-smelling cesspool for sewage and waste disposal than as a habitat for a variety of flora and fauna.

The temporal focus of our study is the early part of the twentieth century, a period during which rapid and sometimes chaotic growth associated with a new era of industrialization was a major force shaping cities. In the Province of Ontario (in which Toronto is located), servicing the expanding mineral, forestry and agricultural sectors of the province's hinterland were important in fuelling industrialization and urbanization in the southern part of the province. Toronto, in particular, achieved phenomenal growth in both population and industrial activity during this time. The city's population tripled between 1871 and 1901 from 86,000 to more than 234,000 people, fueled by increasing industrial employment, an influx of immigrants and the annexation of suburban neighbourhoods. Over the same time span, industrial output rose from over CA \$13 million to over $\$ 58$ million (Goheen, 1979). Industrial growth was particularly rapid between 1880 and 1890. Prominent among the emerging industrial establishment were the Massey Manufacturing Company, which moved to Toronto in 1879 to make agricultural implements (Careless, 1984), and the Gooderham \& Worts distillery, significantly located at the mouth of the Don River and, by the late nineteenth century, producing more proof spirits than any other company in Canada. As Careless (1984: 105) put it: 'Manufacturing advances in the now thickly settled southern Ontario region partly centred in Toronto because of its large amounts of capital and labour, its well-developed entrepôt structure and radiating transport network'. A central facet of this radiating transport network was Toronto's waterfront area around the mouth of the Don.

The institutional focus of our article is the Toronto Harbour Commission (THC), ${ }^{1}$ which has been at the centre of contested processes of shaping and reshaping Toronto's waterfront since its establishment in 1911. Our article will examine the particular role of the THC in territorial expansion, but we note that it had more general ambitions to be not only a harbour minding body and waterfront development organization but also a contributor to more general areas of city building, such as comprehensive transportation planning (Harris et al., 1915). In addition, the Board of the THC believed that the structure of the commission was a relevant institutional model for planning and development in many other cities - that is, the THC's organizational model was promoted as representing more than a 'local interest' (see Gourlay, 1914: 1).

We recognize that, from a local-state theory perspective, a multiplicity of actors is always in the process of negotiating boundaries of the political and that the scales and spaces of environmental policies are constantly being redefined (Desfor and Keil, 2004). This is particularly the case with urban waterfronts, where many governmental agencies come together with overlapping jurisdictions. We are mindful of the important and complex connections that the THC had with other city organizations, and do not intend to minimize the contribution of other network of actors who had a role in policy formulation processes. At the same time, however, we recognize that the THC had the pivotal role of coordinating the participation of different actors and institutions in managing the radical transformation of Toronto's waterfront.

\section{Land production, institutionalization and spatio-temporal fixes}

Recent political ecology literature tends to look at the current period of globalization (Castree, 2002; Robbins, 2002; Keil, 2003; 2005; Swyngedouw, 2004; Braun, 2005; Kaika, 2005; Heynen et al., 2006), but our article is based on an earlier period of

1 The Toronto Harbour Commissioners was established by Government of Canada legislation, 'The Toronto Harbour Commissioners Act 1911'. Throughout this article it is referred to by its common name, the Toronto Harbour Commission. 
capitalist expansion and examines the establishment of a key urban development organization and its role in producing a new form of socio-nature to support an industrializing and quasi-colonial urban region. In some respects, our work is similar to that of While et al. (2004), which also used Harvey's concept of a spatial fix to explore relations between entrepreneurialism and environmentalism. It sought 'to conceptualize forms of local economy-environment relations in the UK' by identifying an 'urban sustainability fix' (2004: 551). Their work was centrally concerned with analysing the formation of local governance policies and organizations, and elaborating how a 'sustainability fix' 'capture[s] some of the governance dilemmas . . created by the current era of state restructuring and ecological modernization' (While et al., 2004: 551). Our article, however, investigates a quasi-colonial situation in an earlier industrial era where socio-nature was manipulated to serve the needs of an expanding economy. It looks to the close engagement between the establishment of a new local-state body and its lead role in producing socio-nature - some have described this as an entanglement between an 'institutional fix' and a spatio-temporal fix (Schoenberger, 2004). We, however, seek to analyse and interpret historical events and to decode a complex political process in which a consensus among dominant political forces and economic elites emerged for coordinating massive state spending on infrastructure development in creating a major extension of the territory of the city.

Our starting point is that dominant sectors in capitalist economies endeavor to manipulate socio-nature to support their logic of wealth accumulation. Generally this takes place through economic and political processes that regulate the application of capital and labour to resources in the production of commodities. However, such attempts to manipulate nature are problematic because of the contradictions which arise not only between classes but also between nature and society. Overaccumulation, one of the great contradictions of capitalist economies, gives rise to a declining rate of profit on investments. In the short term, society may alleviate this immediate problem but the underlying crisis tendencies are not readily resolved. Harvey's notion of a spatial and temporal fix (Harvey, 1982; 2003) addresses the ways capitalist society attempts to divert the excesses of overaccumulation in productive directions and put off crisis tendencies, at least temporarily. Our study of the production of an industrial-oriented urban land mass - a new form of socio-nature - is consonant with his fundamental idea that crises of capitalist overaccumulation can be partially and temporarily solved through spatial and/or temporal expansion of capital. As Schoenberger (2004: 428) commented: 'Harvey's great insight in Limits [to Capital] was that restructuring the geography of capital - altering its very earthly foundations - was a particularly effective way of productively absorbing these excesses'. We believe that combining the dynamics suggested in the notion of a spatio-temporal fix with the concept of socio-nature is particularly useful for understanding a large-scale transformation of the "very earthly foundations' of Toronto. That is, representing the creation of the new land form as a restructuring of the geography of 'very earthly foundations' of Toronto provides us with a framework in which to analyse linkages between the production of socio-nature and political, social and economic practices involved in a major drive toward industrialization and urban expansion.

Harvey first introduced the idea of a 'spatial and temporal fix' in his groundbreaking 1982 book. The Limits to Capital, and has recently revisited its relevance for understanding current imperialist missions and processes of accumulation by dispossession (Harvey, 2003; Castree et al., 2004). The basic idea of a spatio-temporal fix, Harvey suggests, is that crisis tendencies of capitalist overaccumulation may be 'fixed', at least temporarily, by a spatial expansion and temporal deferral of capital's tendency to produce more surplus money capital than can be reinvested at an adequate rate of profitably. Although Harvey seems to have had in mind that many spatial fixes operate at interregional or international scales, in some cases, such 'fixes' take the form of changes to a city's built environment with the construction of large infrastructure projects. He elaborates two dimensions for spatio-temporal fixes, and according to the first: 
A certain portion of the total capital becomes literally fixed in some physical form for a relatively long period of time... Some fixed capital is geographically mobile (such as machinery that can easily be unbolted from its moorings and taken elsewhere) but the rest is so fixed in the land that it cannot be moved without being destroyed. Aircraft are mobile but the airports to which they fly are not.

And, in the second:

The spatio-temporal ' $\mathrm{fix}$ ', on the other hand, is a metaphor for solutions to capitalist crises through temporal deferment and geographical expansion. The production of space, the organization of wholly new territorial divisions of labour, the opening up of new and cheaper resource complexes, of new dynamic spaces of capital accumulation, and the penetration of pre-existing social formations by capitalist social relations and institutional arrangements... provide multiple ways to absorb existing capital and labour surpluses (Harvey, 2003: 65, 66).

In the last 25 years, Harvey's notion of a spatio-temporal fix has been tremendously influential in contemporary social sciences, and numerous analyses and case studies apply the concept or include it in larger theoretical frameworks to explain a wide area of problems and situations, ranging from globalization processes (Uitermark, 2002; Pozo-Martin, 2006; Thomas, 2007) to urban development issues (Braun, 2005; Zunino, 2006). It is important to note the special relevance of Harvey's theory for the study of the dynamics of capital regulation and for understanding both the tensions and the synergy between political power and capital in attempting to abate the crisis tendencies intrinsic to capitalism. Some recent analyses of spatial transformations have focused on the theme of 're-scaling', which attempts to clarify changes in 'scales of operations' of state institutions and capitalist actors, and how these changes are reflected in the reorganization of space (Brenner, 1998; 2000; Marston, 2000; Marston and Smith, 2001; Uitermark, 2002; Somerville, 2004). These studies enriched considerably our conceptual understandings of spatial expansion processes, and remind us of the need to include scale considerations in our analysis.

Both dimensions of Harvey's spatio-temporal fix, the territorial and the spatial, illuminate important aspects of the transformation of Ashbridge's Bay and marsh. In terms of the first dimension, the specific territorial form of the spatio-temporal fix can be readily seen in the creation of an industrial area of some 1,000 acres, the Port Industrial District. That is, labour and capital literally transformed an earlier form of socio-nature into a new and different fixed form as solid land was constructed by lakefilling - a project involving large-scale and radical forms of nature-society interactions. The physical form of these nature-society relationships have been locked in, or fixed, as vast amounts of capital resources, much of which stem from non-local industrial centres, are dedicated to the project for a very long period of time. This new land form, we call industrial nature.

Harvey's first dimension of a spatio-temporal fix also has an interesting discursive association with the notion of 'improvement' (for a more complete discussion of this theme, see Desfor and Prudham, 2006). During the late nineteenth and early twentieth centuries, the doctrine of improvement functioned to legitimate and fuel the production and reproduction of new landscapes. Though the terminology of 'improvement' was not its innovation, the THC elaborated a comprehensive plan for enhancing the economic value and social usefulness of Toronto's waterfront based on this concept. Improvements to Ashbridge's Bay and marsh responded to the dominant representation of these places as being nothing more than a wasteland, a foul-smelling cesspool, and a source of water-borne diseases. In its development plans, the THC represented the natural and the social as constitutive of and inseparable from each other in the production of a more efficient, productive, healthy and rationalized urban ecological landscape in the image of an industrializing city. These spectacular combinations of the social and the natural gave rise to heroic visions of an urban ecological assemblage that was envisioned to be 
Toronto's improved waterfront. The dominant political position that legitimated these projects was based on a universalist political discourse that argued that what was good for the waterfront was always good for all of Toronto. Thus, nature functioned somewhat paradoxically both as an opportunity for and obstacle to the city's grand industrial ambitions; that is, as both the subject and the object of improvement ambitions.

Harvey's second meaning for a spatio-temporal fix, as a metaphor for the way capitalism temporarily resolves its crisis tendencies by opening up new territories, focuses on what Schoenberger (2004: 428) referred to as capitalism's ability 'to productively soak up capital by transforming' its geography. This second dimension of capitalism's drive for an 'escape moment' (Jessop, 2004: 4), concerns the ways longterm investments act to defer crisis conditions in the general conditions of production and 'pre-existing social formations'. This may involve a long period in which attempts to restore capital productivity are focused on opening up new 'dynamic spaces of capital accumulation' (Jessop, 2004: 4) by investments in such things as social infrastructure and education.

The 'opening up' of these new spaces involves, among other things, overcoming contradictions in existing social relations by moving to establish an ensemble of new social practices and institutions that facilitate and participate in developing a regime of accumulation, and more particularly, realizing investments in massive infrastructures. We argue that the THC is best understood as one of the institutions within such an ensemble. As we discuss more fully below, the political struggles by which this institution was established reveal much about underlying social relations and the ideological positions of the dominant groups in society.

One of the fundamental issues in those political struggles was the development of a discourse by which a public agenda for the waterfront 'problem' was defined. Marxist and post-Marxist theories concur that having the authority to define a problem, or to determine the process by which it is defined, reflects important power relations in society (Lukes, 1974; Laclau and Mouffe, 1985; Laclau, 1990). According to this understanding, power relations are manifested not only through the formalized interactions between state institutions and individuals, but also through the discursive mechanisms involved in controlling the agenda and the language of public debates. Although it is less transparent and seemingly less coercive, this form of power represents a fundamental dimension of social control and a key element in mobilizing public support for certain collective projects.

To elaborate on the relevance of a spatio-temporal fix for Toronto's waterfront, we now consider Toronto's position as an emerging industrial city, and the discursive construction and material reconfiguration of its waterfront as both opportunity for and obstacle to this emergence.

\section{Representing Toronto's waterfront problem as a big development project}

The last decades of the nineteenth and the first of the twentieth centuries have been called Canada's industrial era. Booming agricultural and resource development fuelled industrial expansion. As Innis chronicled, Canada's political economy was forged in the staples trade as a key supplier of empires, first through its colonial ties to Britain, and, increasingly, to the emerging economic giant to the south (Drache, 1995). Increasingly, extensive staples geographies gave rise to intensive, urbanizing development, as industrial processing and transportation linkages fuelled the growth of major Canadian centres. In this context, Toronto faced a dilemma.

Toronto's boosterish political and economic elite, anxious to propel the city (and themselves) particularly in relation to Montreal, saw the waterfront as strategic, but in need of improvement. They argued that bringing in and transporting out goods in the 


\section{A political ecology of Toronto's Port Industrial District}

service of the city and industry required major improvements to transportation facilities. An earlier era of lake filling had created solid land on the waterfront that served the railroads by providing a foundation on which to lay tracks. But, businesses complained bitterly about the high transport rates stemming from the railroads monopoly of transport facilities, and many central areas of the waterfront saw major battles among residents, shipping interests and the railroad companies for valuable locations and strategic sites (see Mellon's 1974 analysis of the first railway penetration in the mid-1880s). The scale of the new opportunities for capital circulation provided by grand infrastructure projects is evident in railway development in Ontario; by 1911 the railways employed 36,700 people and largely determined the growth of several towns and the development of numerous industries (Drummond, 1987: 253). ${ }^{2}$ Improving or expanding waterways transportation was considered equally important, especially in relation to the growth of industrial cities. Well known examples of such water-related projects are the various stages for deepening the Welland Canal and St Lawrence Canal, and the modernization of several ports, such as St John's port in 1910.

Industrialists and commercial interests took note of the opportunities these investments in transportation infrastructure projects had for Toronto. If significant new port facilities, built on solid land and giving access to deep water, were constructed, then Toronto's position in Great Lakes shipping would be enhanced. To achieve this goal, industrial interests and city boosters could rally around filling in the Ashbridge's Bay and marsh.

At the beginning of the twentieth century, the political discourse of the THC and its supporters began to represent Toronto's waterfront as though it were a single 'waterfront problem', which was defined by combining and redefining a number of issues that were to some extent spatially and functionally related, but institutionally disconnected. The dimensions of this problem were neither necessarily interconnected nor were they problems of equal importance from the public perspective. The actors and the supporters involved in the establishment of the THC constructed the 'waterfront problem' for the public. Issues of different magnitudes, often originating in different causes, and most likely requiring different particular solutions, were incorporated into the THC development agenda and defined simply as elements of a more comprehensive 'waterfront problem'.

Discussion of the major dimensions of Toronto's waterfront problem began with the inadequate port regulatory authority and consequent difficulties with shipping in the harbour. The body responsible for keeping the harbour free from obstructions and for dredging slips was the Commissioners of the Harbour of Toronto - the predecessor to the THC and commonly called the Trust. The inadequacy of the Trust related not only to its limited power to raise funds and regulate shipping activities, but also to charges of corruption. For example, in 1909, an important manufacturing site on the waterfront was sold for what was reported to be about one-twentieth of its market value (Middleton, 1923). As early as the 1870 s, complaints were all too commonly heard about obstructions that made the harbour unsafe for shipping (Middleton, 1923: 446). Ship captains and owners reported that conditions (both floating logs and shallow water) were so dreadful that they avoided using the harbour. The commercial viability of the port was being jeopardized, they claimed, and the competitive position of shipping was losing out to railway companies. These and other problems made it clear that, by the turn of the twentieth century, the Trust 'had ceased making any positive contributions to the improvement of the harbour' (O'Mara, 1976: 15), and a new regulatory body was needed if a 'modern' port and harbour were to be established.

2 The importance of state spending for infrastructure projects is well known to economic historians as grand infrastructure projects create opportunities for exploiting new natural resources and for diversifying the manufacturing sector or for strengthening particular economic sectors, such as the steel industry. That is, both 'backward linkages' and 'forward linkages' can provide new spaces for fixing capital (Marr and Paterson, 1980: 13). 
As important as the Trust's inadequacy was for a turn toward a new institutional arrangement for waterfront development, this was only one of the representations of the waterfront problem. There were many others of equal importance, including a threat of water-borne diseases such as cholera and typhoid from unsafe sewage treatment and waste disposal; high shipping rates due to a lack of competition between water and rail transportation modes; a general distrust of local government's ability to handle the complexities of a large and rapidly growing industrial, financial and commercial city; the lack of park space for city residents; and, perhaps most loudly proclaimed, the city's need for 'deep water and good land' (Gourlay, 1914: 2) to fuel its continued expansion.

All these were articulated as dimensions of a singular, although complex, "waterfront problem', the immediate effect of which was to justify large-scale intervention in the form of a 'big development project'. The eventual emergence of the THC as the dominant actor in the process of regulating, managing and transforming the waterfront can be understood precisely as reflecting this new representation of development and planning. The unprecedented institutional powers the THC was to receive derived from an ambition to include a wide range of urban development issues as parts of a single and, it was hoped, manageable problem. And the adoption of its Waterfront Development Plan (Toronto Harbour Commissioners, 1912), just 12 months following its establishment, codified its plans for a massive transformation of the waterfront, with the Port Industrial District as its centre piece. Thus, examining the emergence of the THC as the main regulatory body of Toronto's waterfront helps us understand how a new form of socionature was produced.

\section{The referendum}

The campaign to establish a new waterfront development body evolved over a decade or so and during this period the 'waterfront problem' was clearly articulated. This campaign came to a head on 2 January 1911, when Toronto's duly registered electorate went to the polls to elect a city government and to express its preferences on a series of development issues. Among the referendum questions on that Election Day, two addressed the waterfront problem. One was concerned with funding particular infrastructure improvements, and the other asked a broader question:

Are you in favor of the control and development of Ashbridge's Bay and the waterfront in the city's interest by a commission having a majority of its members appointed by the city? (City of Toronto, 1911: 129).

As framed by the referendum question, control over and accountability of the commission was vague and, in some respects, misleading. The reference to the 'city's interest' says nothing about the particular mechanisms of defining the public interest in the context of Toronto's waterfront development. Similarly, the organization of the new commission and its place within broader government structures were not explicitly mentioned in the referendum question and had not been an issue of open public discussions or consultations. Under these circumstances, it is likely that the public had little access to relevant information for determining the extent to which 'a commission having a majority of its members appointed by the city' was equivalent to a commission controlled by the City Council and accountable to Torontonians. ${ }^{3}$

The referendum question, as it appeared on the ballot that day, sounded too good to oppose. Fifteen years after the referendum, the report of the first Royal Commission inquiring into Toronto's waterfront development remarked that the form of the question

3 The extent to which the City Council has control of the THC has been debated for decades and has given rise to innumerable controversies and even a fair number of law suits. 
was very favourable for those who wished the improvements to be made. It also noted with an interesting foreshadowing to our study: 'There are some ratepayers, however, who would like to know by whom and by what methods public opinion was created in favour of this large undertaking' (Canada, 1927: 8).

Leading up to the referendum vote, the Toronto Board of Trade, the Toronto City Council and local newspapers all engaged in fervent discussions about the merits of a new waterfront development authority, which, no doubt, had some influence on public opinion. The Board of Trade, the first of these groups, represented the interests of the business community and brought together a group of elite businessmen, including the Canadian Manufacturers' Association, the Retail Merchants' Association and the District Labour Council, which ran a well financed and organized political campaign. It published a leaflet proclaiming in bold points that a 'Yes' vote would be a major benefit to Torontonians with the following expectations (Wickson, 2002):

- Toronto's greatest asset would be developed;

- a neglected Ashbridge's Bay would become worth many millions of dollars;

- the harbour would pay for its own development and be made into the finest harbour on the Great Lakes;

- Toronto would be one of the greatest industrial centres on the continent; and

- the harbour would be managed like a business.

A close interrelationship between economics and politics with nature is central to the underlying message of this leaflet. The economic benefit - development of the city's greatest asset on a self-sustaining basis - is attributed to a new government organization that would be run on a business-like basis - thus avoiding the ineptitude and corruption associated with local government, but seemingly keeping the benefits of development in public hands. Both of these benefits are made possible by replacing the foul-smelling and worthless swamp of Ashbridge's Bay with a grand industrial district that would contribute to making one of the finest harbours on the Great Lakes.

One of the most controversial issues leading up to the referendum was how the new urban development organization would be structured within a local state apparatus. The Board of Trade and its allies supported the formation of a 'national' harbour commission - that is, a commission established under national legislation with the majority of its board members being appointed by the national government. Two reasons were fundamental to their position: first, they thought that a 'national' commission was a necessary precondition for the Dominion Government to contribute to the funding of the project; and, second, they wanted to ensure that profits from land development would be reinvested specifically in port and harbour development - rather than other city projects. This latter point is central to the Board of Trade's position that the city's economic growth begins at the waterfront and the management of this venture should be under the direction of an urban development corporation outside of usual government activities. The Board had a longstanding position in favour of systematic development of the waterfront for industrial and commercial purposes and supported large-scale lakefilling as a boost for Toronto's economic growth. Their rhetoric prominently described the way that Toronto could build the finest port and harbour on the Great Lakes and become a major urban region. In their view, a waterfront industrial district full of water-related manufacturing activities and warehousing firms was not only integral to an expanded port, but provided a justification for investment in port expansion. A fine example of this discourse had appeared in a Toronto newspaper a few years earlier:

Toronto is to become the Pittsburg of Canada. That heretofore despised region known as 'The Marsh' is to be the site of one of the great iron and steel plants in America, the headquarters of the manufacturing industries that will supply the cars and the equipment for the Canadian Northern, and the pig iron for the foundries and factories of the city. Toronto has been a city of light manufacturing up till the present time. It will soon be the biggest producer in Ontario of the basic material of twentieth century prosperity - iron and steel (The Globe, 1907: 1). 
The second group influencing public opinion, Toronto's newspapers, contributed to discussions with their reports of waterfront 'problems' and editorial pieces. They helped to consolidate a negative public perception about the marsh and supported proposals to transform Ashbridge's Bay into an industrial district. While they generally supported filling in the marsh, The Toronto Daily Star, The Globe, and The Evening Telegram took different positions with respect to whether the new organization should be part of a 'local' or 'national' government.

The Toronto Daily Star favoured a local commission - sometimes referred to as a 'civic' commission. It argued: 'There seems to be no reason why the elected representatives of the people should not remain in direct control of the waterfront. To elect men to control the city's fund, and then to hand over the spending power to other sets of men, seems somewhat of an anomaly' (The Toronto Daily Star, 1910: 6). However, it did recognize the importance of the Dominion Government's funding of waterfront development and suggested that if those funds are not forthcoming then the city should proceed with its own plans.

The Globe was the most enthusiastic supporter of a 'national' harbour commission. A national commission was important both for controlling the commission's appointments to the Board and as a discursive argument supporting the port's 'national' importance. The Globe supported a Board of Directors composed of three national-government appointed City representatives and two from the Dominion Government. It mentions that a three plus two Board would make the "Toronto harbour the finest on the Great Lakes, and make the city one of the great industrial centers of the continent. An improved harbor means more work ... more wages, cheaper freight, while a commission would secure a wise, businesslike and continuous management' (The Globe, 1910b: 8). In 1906, an article from The Globe described an initiative by the industrialists Messers Mackenzie and Mann to invest in a manufacturing establishment at Ashbridge's Bay as being of 'national importance' and supported the idea of providing 'suitable lands' in the area by filling Ashbridge's Bay (The Globe, 1906: 12). The terms 'national' and 'public interest' were later incorporated in the language of the THC (see, for example, Gourlay, 1914: 3). The economic and political justification for connecting the creation of an industrial district at Ashbridge's Bay with the idea of national interest was mainly based on the hope that rapid industrialization was a key element in transforming Toronto into a dominant economic centre of the region. The Globe's position was summarized with: "Answer the Commission question with a "Yes" and vote for the harbour improvement money by-law' (The Globe, 1910c: 4).

The Evening Telegram, with its outspoken populist publisher John Ross Robertson, gave more attention to Toronto's waterfront development than the other articles. It commented on various methods for appointing Board members, financial accountability and the powers of the future commission. It recommended voting against the referendum question and advocated a two commission solution in place of a single development body. While it did support filling in Ashbridge's Bay, The Telegram advocated 'A Dominion Government commission working to secure navigable water for deep vessels in the port of Toronto and a civic commission working to plan docks and otherwise develop the city's property...' (The Telegram, 1910a: 14). The two commission solution, it argued, would encourage Dominion Government participation in the project, and yet allow for the city to control its waterfront lands in its interest.

In sum, these three daily papers all supported the radical transformation of the waterfront by filling in Ashbridge's Bay and marsh to create an industrial district, but they had somewhat different positions about the structure of the institution that should govern the district's construction and operations. They supported the idea that major changes in the management of the waterfront were urgently needed, that the value of Ashbridge's Bay as a natural site was negligible, and that filling it in was the only possibility for 'making the marsh of any real value for the city' (The Globe, 1907: 1).

The third group to influence public opinion, Toronto City Council, focused more on the structure and control of a possible harbour commission than on the filling in of the 
marsh - as had been the case with the newspapers. ${ }^{4}$ That management should be invested in a commission outside the usual city government did not generate much debate - indeed, an interesting position for a city council. Even during the final weeks prior to the referendum, however, the City Council continued to debate whether the commission should be 'local' or 'national'. About a month prior to the referendum, Toronto's Mayor Geary expressed opposition to the establishment of a 'national' harbour commission. He wanted a 'local' commission in which all Board members would be appointed by the City Council (The Globe, 1910a: 1, 4). He took the position that a 'local' commission with exclusive representation from the city should administer taxpayers' property. The city's land should be developed, he argued, in the city's interests. If Ashbridge's Bay were to be developed as an industrial district then the profits from this city-owned land should be controlled by a 'local' commission. He countered the argument that national representation was necessary for funding by suggesting that the Dominion Government is not 'so small as to refuse assistance if we have a civic commission' (The Globe, 1910a: 4). Only weeks before the referendum, however, Mayor Geary succumbed to pressure from industrial and economic influences, reversed his position and supported the position of the Board of Trade: 'These are public-spirited gentlemen, and we feel it is due to them to let their plan go before the ratepayers unmarred by any scars of contest. Therefore we will not oppose the by-law' (The Telegram, 1910b: 1).

When voters went to the polls that 2 January, there was little doubt about the outcome of the referendum question. With the Toronto Board of Trade leading a well run campaign for the 'yes' side, the failure of resistance in the City Council, only a single newspaper voicing opposition to the referendum, and very favourable wording of the referendum question, it is not surprising that a resounding $76 \%$ of voters indicated they did indeed wish both to have Ashbridge's Bay developed and to have control of this development put into the hands of a commission that would be outside the usual structure of city government (City of Toronto, 1911: 133). Opposition to the referendum came primarily from an area where landowners stood to lose their direct access to the lake from filling in the marsh.

\section{The THC and land production}

In May 1911, about five months after the referendum, the Dominion Government of Canada ushered in a new era of waterfront development in Toronto with the establishment of the THC (Canada, 1911). The newly established THC represented the end of a period of contestation in which various factions of capital came together to institutionalize a set of social relations and undertake a major urban ecological transformation of one form of socio-nature into another. The establishment of the THC, however, also marks the beginning of a new period during which it was the lead organization, not only for managing a many faceted waterfront problem, but also for shepherding in massive industrial, transportation and park infrastructure projects supporting increased industrial developments in a rapidly changing city at the turn of the twentieth century. The THC had unprecedented powers and acquired ownership of virtually all waterfront lands, the right to raise capital, to expropriate land, and to operate largely independently of city, provincial or national governments. They were successful in obtaining control of virtually all waterfront property through purchases, expropriation or exchange (Canada, 1927).

4 For decades the City Council, the Board of Trade and the daily newspapers were concerned with developing the mouth of the Don River and Ashbridge's Bay (Desfor, 1988). The Board even put forward its own plan to develop the area in 1910. It seems that as the campaign for a yes vote on the referendum question approached, the City, the Board and the newspapers focused more on the structure of the new organization than its particular plans for development. 
The THC took the lead in creating a new industrial nature as the centre piece for its remake of the waterfront. Guided by its chief engineer, E.L. Cousins, the THC - that is, the state, at both national and local scales - was centrally involved in putting in place a system that, in effect, manufactured land in the marsh by industrializing the then common but casual practice of dumping all sorts of urban wastes into the lake. Beginning in 1914 and lasting for more than two decades, the THC managed an impressive industrial system of land production (Canada, 1927). The THC organized a highly capital-intensive and mechanized process that was designed to closely control production and dominate the environment, and, in addition, did not recognize interdependencies between those production processes and the environment (O'Connor, 1994). Not only were the processes and labour relations that constructed the land industrial, but also the form and function of socio-nature that resulted from the production process reflected the objectives of industrial capitalism. Dock walls outlined linear boundaries creating regular geometric shapes behind which solid land was to be created. This land form itself was consistent with the proposed grid pattern of streets and facilitated manufacturing, warehousing and commercial sites all supported by piped infrastructure - all the sites were planned to be accessible to electricity and connected to railroad sidings. The walls were constructed with a mixture of human and non-human nature in which it was not possible to know where one form began and the other ended. British Columbia fir trees were harvested from the western end of the country, transported more than a thousand miles, and machined into 'tongue and grooved close sheet piling' (Cousins, 1948: no pagination). The manufactured lumber piling itself was reinforced with concrete, another engineered form of socionature. To obtain solid material for fill, the THC committed intensive capital equipment to hydraulically dredging the lake bottom. Dredging not only served as a source of material for land fill, but it also created a navigable depth of $30 \mathrm{ft}$ in the harbour. The largest dredge on the Great Lakes at the time churned its huge blades to stir up the lake bottom, and powerful pumps moved this dredgate through an extensive system of pipes to its desired location. In addition to the approximately 35 million cubic yards of dredged material, earth was hauled from outside the city and dumped behind the walls.

Funding of such a massive project required particularly stable institutional arrangements and points to an important relationship between state spending and private financing in opening up opportunities for new spatial fixes. The exceptionally large sum of money required for the big development project required a strong banking sector. In this context, it is crucial that numerous banks had opened branches in Toronto, others had moved to Toronto, and several mergers took place in the second half of the nineteenth century. This contributed to the emergence of Toronto as the most important financial centre in Canada (Norrie and Owram, 1996: 277).

Additionally, the international economic and financial context seemed favourable for guiding funds in the direction of such large development enterprises. In the first decade of the twentieth century, European economies grew significantly and the major European banks were particularly active in funding large industrial projects and infrastructure development internationally (Crouzet, 2001: 130). European exports of capital were particularly high during that period, with the UK's investments abroad being the highest and reaching, in some periods, more than half of its financial surplus. Thus, in 1914 foreign investments made by the UK were calculated to be equivalent to approximately 18.5 billion in 2001 US dollars (Crouzet, 2001: 156-9). Toronto's strong banking sector, coupled with rising productivity, made it possible for both the UK and the US to strengthen their roles and positions in the Canadian economy. In relative terms, foreign investments in 1911 made by British companies in Canada made up approximately $77 \%$ of total foreign investments, while US companies' investments reached 20\% (Historical statistics of Canada in Norrie and Owram, 1996: 321-2).

The THC, with its special combination of statutory powers and business-like practices, played a vital role in attracting and mediating international private-sector investments for the construction of a new territory. It used these powers to raise money by issuing a series of debentures amounting to a total of approximately $\$ 25,000,000$ 
(Cousins, 1921) - the equivalent of almost half a billion 2007 Canadian dollars. The first million dollars of the initial bond issue was sold to William A. Reid and Company of New York. Reid was the only firm that was asked for a quotation, despite two other firms having made bids with more favourable conditions (Canada, 1927: 22). A million dollars of each of the second and third series of bonds was also sold to Reid and Company (Canada, 1927: 22). Sales of these debentures were arranged through the National Trust Company, the Dominion Securities Corporation, and the Toronto General Trusts Company, and sold in London, New York and Toronto. It is clear that the THC had power not only to funnel financial surpluses to Toronto from the US and from Britain, one of Canada's dominant colonial centres, but also to attract these funds from the private sector. As with other colonial situations, investment opportunities in the periphery provided private capital in the centre with productive outlets through the creation of new forms of socio-nature.

In short, the THC was the central player in processes that produced an urban landscape intended to support an economy in which striving for profitability would drive an incessant output of manufactured commodities from various forms of socio-nature and the coordinated work of labour; it had produced industrial nature.

\section{Conclusions}

Our aim in this article has been to understand how a particular form of socio-nature, the Port Industrial District, was produced through intertwined human and non-human processes and how this new land form supported wealth accumulation in Toronto during the early twentieth century. As Hudson notes (1996: 1) 'the reclamation of land for urban development is much more common than is generally realized and ... far from being a phenomenon which occurs only in special circumstances, is a normal process of city expansion'. It is this 'normal process of city expansion' that has led us to examine the historical case of land creation on Toronto waterfront. Political events leading to the establishment of the THC, and their discursive representations, reveal much about how this new institution and its plans for a spatio-temporal fix were the basis for a major urban expansion promoting industrialization as the primary logic for wealth accumulation. Supporters of the THC articulated a 'waterfront problem' for the public that relied on a powerful organization largely free of local and national government control as the primary institution to carry out production of a major urban expansion. The filling in of what was then represented to be a foul-smelling wasteland and breeding ground for all sorts of diseases was the centre piece of plans for producing the Port Industrial District.

The Port Industrial District, a particular form of socio-nature that we have called industrial nature, synthesizes many highly intertwined human and biophysical processes. Within that physical land form are embodied capital-intensive and mechanized production processes, an ideology that regards the environment as a resource, and political practices that support the dominant sector of an economic system in which social relations are guided by the continual striving for profitability by manufacturing commodities from socio-nature and the work of labour.

Our historical analysis of the THC and its Port Industrial District strengthens Harvey's hypothesis about the role of spatio-temporal fixes in helping to resolve crises of overaccumulation and expands its range of application. As Schoenberger (2004: 428) noted, a spatio-temporal fix opens up new territories by productively soaking up excess capital and transforming its geography. The production of land is a particular case of such a spatio-temporal fix, and one which is quite usual in urban-waterfront expansion. What we might call a 'land-creation fix' restructures waterfront geographies in three specific ways: first, it produces a commodity (land) that can be bought and sold and thus has an exchange value; second, the produced land has a use value as an input for production processes (in our case, as an industrial landscape); and third the territory created by the produced land provides for new spatial relations in the city. 
As Harvey suggested, new institutional arrangements tend to accompany the emergence of a spatio-temporal fix. The THC was indeed such an institutional innovation with a multi-scale legislative dimension and an ability to attract and manage investments for creating land. The THC influenced, and was influenced by, broader patterns of economic and regulatory patterns. In particular, its organizational structure - greatly influenced by the urban reform movement of the time - institutionalized publicly unaccountable decision-making and solidified a close relation between businesses and city politics based on special interests. ${ }^{5}$

In addition to illuminating the ways crises of overaccumulation are temporarily resolved through geographic restructuring, the notion of a spatio-temporal fix enables us to consider relationships between the institutionalization of social relations and the production of a new form of socio-nature. As Harvey (1996: 184) so concisely noted: 'One path towards consolidation of a particular set of social relations ... is to undertake an ecological transformation which requires the reproduction of those social relations in order to sustain it'. The case of Toronto's waterfront development at the beginning of the twentieth century shows how important the establishment of the THC was for both consolidating a new set of social relations, and producing a new set of spatial relations in the city.

The extent to which the establishment of the THC is indicative of an 'institutional fix' is an interesting hypothesis deserving of additional research. That the THC should be seen as part of the local state and an ensemble of organizations within a mode of social regulation is clear, but the extent to which its establishment should be seen as a marker for a new regime of accumulation is not. Industrialization had been underway in Toronto for some decades by the time the THC was established in 1911. The THC's development of the Port Industrial District was intended to propel the city forward on an already established path as a capital-expansive regime of accumulation and this new institution seems to have consolidated a set of emerging social relations and practices. Thus, it appears that the new institutional arrangement may not have marked the formation of a new regime of accumulation but instead consolidated and propelled forward an existing one. While it is premature to come to a conclusion about whether the establishment of the THC represented an institutional fix - in the sense that new institutional arrangements are intended to lubricate the wheels for a new accumulation regime - we do agree, however, with Peck and Yeung's (2003) finding that new governmental organizations are required by urban expansion. The THC did indeed constitute a different institutional state space for regulating nature-society relationships, in general, and, in particular, for producing an industrial land form by constituting and managing a process of guiding investment into the built environment.

The establishment of the THC represented more than founding a new organization that could solve an 'integrated waterfront problem' by providing infrastructure and a site for an industrial district. It defined an ideological frame in which the 'waterfront problem' was rationalized and managed. It exercised political power in specific social contexts, challenging the liberal representation of institutions as mechanisms that generate ideologically neutral decisions. The establishment of the new organizational structure with its special regulatory and development powers was integral to the production of the Port Industrial District. It made possible the production of a major urban expansion through the creation of a new industrial form of socio-nature.

Gene Desfor (desfor@yorku.ca) Faculty of Environmental Studies, York University, 4700 Keele Street, Toronto, Ontario M3J 1P3, Canada and Lucian Vesalon (vesalon@polsci.uvt.ro), Faculty of Political Science, Philosophy and Communication Studies, West University, 4 Parvan Blvd, Timisoara, 300233 Romania.

5 For a discussion of the urban reform movement in Canadian cities, see the chapters by J. Weaver, P. Rutherford and J. Fingard in Stelter and Artibise (1979). 


\section{References}

Barnett, J.M. (1971) Ashbridge's Bay. Ontario Naturalist December, 24-6.

Braun, B. (2005) Environmental issues: writing a more-than-human urban geography. Progress in Human Geography 29.5, 635-50.

Brenner, N. (1998) Between fixity and motion: accumulation, territorial organization and the historical geography of spatial scales. Environment and Planning D: Society \& Space 16.4, 459-81.

Brenner, N. (2000) The urban question as a scale question: reflections on Henri Lefebvre, urban theory and the politics of scale. International Journal of Urban and Regional Research 24.2, 361-78.

Bunce, S. and G. Desfor (2007) Introduction to 'Political ecologies of urban waterfront transformations'. Cities: The International Journal of Urban Policy and Planning 24.4, 251-8.

Canada (1911) The Toronto Harbour Commissioners Act-1911. 1-2 George V, Chapter 26.

Canada (1927) Commission to Investigate the Transactions of the Toronto Harbour Commissioners. Toronto Port Authority Archives [previously known as the Toronto Harbour Commissioners Archives].

Careless, J.M. (1984) Toronto to 1918: an illustrated history. James Lorimer, Toronto.

Castree, N. (1995) The nature of produced nature: the materiality and knowledge construction in Marxism. Antipode 27.1, 12-48.

Castree, N. (2002) False antitheses? Marxism, nature and actor-networks. Antipode 34.1, $111-46$.

Castree, N. and B. Braun (eds.) (2001) Social nature: theory, practice and politics, Blackwell, Oxford and New York.

Castree, N., J. Essletzbichler and N. Brenner (2004) Introduction: David Harvey's The Limits to Capital: two decades on. Antipode 36.3, 401-5.

City of Toronto (1911) Minutes of City Council 1910. Appendix C. City Printers, Toronto.

Cousins, E.L. (1921) Toronto harbour improvements. World Ports 9 May, 59-80.

Cousins, E.L. (1948) The Port of Toronto: the development of a major port of the lakes of Canada. The Dock and Harbour Authority September.
Crouzet, F. (2001) A history of the European economy, 1000-2000. University Press of Virginia, Charlottesville and London.

Demeritt, D. (1996) Social theory and the reconstruction of science and geography. Transactions of the Institute of British Geographers 21.3, 484-503.

Desfor, G. (1988) Planning urban waterfront industrial districts: Toronto's Ashbridge's Bay, 1889-1910. Urban History Review $17.2,77-91$.

Desfor, G. and R. Keil (2004) Nature and the city: making environmental policy in Toronto and Los Angeles. University of Arizona Press, Tucson.

Desfor, G. and S. Prudham (2006) Deep water and good land: socio-natural transformation of Toronto's industrial waterfront. Presentation to the Association of American Geographers, Chicago.

Drache, D. (ed.) (1995) Staples, markets, and cultural change: selected essays of Harold Innis, 1894-1952. McGill-Queens University Press, Montreal.

Drummond, I. (1987) Progress without planning: the economic history of Ontario from confederation to the second world war. University of Toronto Press, Toronto.

Gandy, M. (2002) Concrete and clay: reworking nature in New York City. MIT Press, Cambridge and London.

Goheen, P.G. (1979) Currents of change in Toronto, 1850-1900. In G.A. Stelter and A.F.J. Artibise (eds.), The Canadian city: essays in urban history, MacMillan, Toronto.

Gourlay, R. (1914) Basic Principles for a water-front development as illustrated by the plans of the Toronto Harbour Commissioners. Address to the National Conference on City Planning, Toronto, May. THCA Archives: RG 1/5, box 2, folder 15.

Haraway, D. (1991) Simians, cyborgs and women - the reinvention of nature. Free Association Books, London.

Harris, R.C., F.A. Gaby and E.L. Cousins (1915) Radial railway entrances and rapid transit. Report to the Civic Transportation Committee, City of Toronto, Brigdens Ltd, Toronto.

Harvey, D. (1982) Limits to capital. Oxford University Press, Oxford.

Harvey, D. (1996) Justice, nature and the geography of difference. Blackwell, Oxford and New York. 
Harvey, D. (2003) The 'new' imperialism: accumulation by dispossession. In L. Panitch and C. Leys (eds.), Socialist register 2004: the new imperial challenge, Merlin Press, London.

Heynen, N. and E. Swyngedouw (2003) Urban political ecology, justice and the politics of scale. Antipode 35.5, 898-918.

Heynen, N., M. Kaika and E. Swyngedouw (eds.) (2006) In the nature of cities: urban political ecology and the politics of urban metabolism. Routledge, London and New York.

Hudson, B. (1996) Cities on the shore: the urban littoral frontier. Pinter, London and New York.

Jessop, B. (2004) Spatial fixes, temporal fixes, and spatio-temporal fixes [WWW document]. URL http://www.lancs.ac.uk/ fss/sociology/papers/ jessop-spatio-temporal-fixes.pdf [accessed on 2 April 2007].

Kaika, M. (2005) City of flows: modernity, nature, and the city. Routledge, New York and London.

Keil, R. (2003) Urban political ecology. Urban Geography 24.8, 723-8.

Keil, R. (2005) Progress report - urban political ecology. Urban Geography 26.7, 640-51.

Kyte, K.C. (1910) Old Toronto: excerpts from landmarks of Toronto by John Ross Robertson. MacMillan, Toronto.

Laclau, E. (1990) New reflections on the revolution of our time. Verso, London and New York.

Laclau, E. and C. Mouffe (1985) Hegemony \& socialist strategy. Towards a radical democratic politics. Verso, London and New York.

Latour, B. (1993) We have never been modern. Harvester Wheatsheaf, London.

Lukes, S. (1974) Power: a radical view. Macmillan, London.

Marr, W.L. and D.G. Paterson (1980) Canada: an economic history. MacMillan, Toronto.

Marston, S.A. (2000) The social construction of scale. Progress in Human Geography 24.2, 219-42.

Marston, S.A. and N. Smith (2001) States, scales and households: limits to scale thinking? A response to Brenner. Progress in Human Geography 25.4, 615-19.

Mellon, F. (1974) The development of the Toronto waterfront during the railway expansion era, 1850-1912. Unpublished
PhD dissertation, Department of Geography, University of Toronto.

Middleton, J.E. (1923) The municipality of Toronto: a history. Volume 1. The Dominion Publishing Company, Toronto and New York.

Norrie, K. and D. Owram (1996) A history of the Canadian economy. Harcourt Brace, Toronto.

O'Connor, M. (1994) Codependency and indeterminacy: a critique of the theory of production. In M. O'Connor (ed.), Is capitalism sustainable, Guilford Press, New York and London.

O'Mara, J. (1976) Shaping urban waterfronts: the role of Toronto's Harbour Commissioners, 1911-1960. Discussion Paper No. 13, Department of Geography, York University, Toronto.

Peck, J and H. Yeung (eds.) (2003) Remaking the global economy: economic-geographical perspectives. Sage, London.

Pozo-Martin, G. (2006) A tougher Gordian knot: globalisation, imperialism and the problem of the state. Cambridge Review of International Affairs 19.2, 223-42.

Robbins, P. (2002) Obstacles to a first world political ecology? Looking near without looking up. Environment and Planning $A$. 34, 1509-13.

Schoenberger, E. (2004) The spatial fix revisited. Antipode 36.3, 427-33.

Seton, E.T. (1940) Trail of an artist-naturalist: the autobiography of Ernest Thompson Seton. Charles Scribner's Sons, New York.

Smith, N. (1984) Uneven development: nature, capital and the production of space. Blackwell, Oxford and New York.

Somerville P. (2004) State rescaling and democratic transformation. Space and Polity 8.2, 137-56.

Stelter, G.A. and A.F.J. Artibise (eds.) (1979) The Canadian city: essays in urban history. Macmillan of Canada, Toronto.

Swyngedouw, E. (1996) The city as a hybrid: on nature, society and cyborg urbanization. Capitalism Nature Socialism 7.2, 65-80.

Swyngedouw, E. (2004) Social power and the urbanization of water: flows of power. Oxford University Press, Oxford.

The Globe (1906) Iron smelters will come here. The Globe 11 October, 12.

The Globe (1907) Moose mountain furnaces will make a Canadian Pittsburg in Toronto's marsh. The Globe 12 October, 1. 


\section{A political ecology of Toronto's Port Industrial District}

The Globe (1910a) Scheme killed, says Mr. Gage. The Globe 2 December, 1, 4.

The Globe (1910b) In the civic arena. The Globe 28 December, 8.

The Globe (1910c) Development of Toronto's Harbor. The Globe 31 December, 4.

The Telegram (1910a) Advance Toronto. The Telegram 3 December, 14.

The Telegram (1910b) 'Oh, shut up' said McBride repartee at council meeting. The Telegram 6 December, 1.

The Toronto Daily Star (1910) Toronto's Harbor. The Toronto Daily Star 18 June, 6.

Thomas, N. (2007) Global capitalism, the anti-globalization movement, and the Third World. Capital and Class 92, 45-78.

Toronto Harbour Commissioners (1912) Toronto Waterfront Development, 1912-1920. Toronto Harbour Commissioners, Toronto.

Uitermark, J. (2002) Re-scaling, 'scale fragmentation' and the regulation of antagonistic relationships. Progress in Human Geography 26.6, 743-65.

Whatmore, S. (2002) Hybrid geographies. Routledge, London and New York.

While, A., A. Jonas and D. Gibbs (2004) The environment and the entrepreneurial city: searching for the urban 'sustainability fix' in Manchester and Leeds. International Joumal of Urban and Regional Research 28.3, 549-69.

Wickson, T. (2002) Reflections of Toronto Harbour: 200 years of port activity and waterfront development. Toronto Port Authority, Toronto.

Zunino, H.M. (2006) Power relations in urban decision-making: neo-liberalism, 'techno-politicians' and authoritarian redevelopment in Santiago, Chile. Urban Studies 43.10, 1825-46.

\section{Résumé}

Cet article analyse les pratiques politiques et économiques impliquées dans la production d'une forme industrielle de socio-nature, le quartier industriel portuaire de Toronto, dans les premières décennies du XX $X^{e}$ siècle. À partir de documents historiques de cette époque et de concepts contemporains propres à la théorie urbaine, est analysée la création d'une zone terrestre considérable et d'une extension du Sud de Toronto dans un cadre d'écologie politique. Nous associons explicitement le concept de socio-nature et les dynamiques suggérées par les théories de l'expansion du capital et de l'expansion spatiale, ce qui recentre la "nature" dans l'appréhension des processus d'aménagement urbain. À notre avis, les commissaires du Havre de Toronto, organisme central chargé de la création de ce terrain, ont davantage traduit les préférences idéologiques et les intérêts économiques des élites locales qu'un projet institutionnel efficient pour résoudre un "problème de front de mer" multi-dimensionnel. La Commission du Havre et ses partisans ont imaginé et défendu le nouveau quartier industriel, composante-clé du plan d'aménagement du front de mer de 1912, comme une stratégie d'ensemble visant à intensifier l'industrialisation et l'essor de la ville. Or, l'énorme projet d'infrastructure se comprend mieux en tant que solution spatio-temporelle pour absorber des capitaux de manière productive par le biais d'une expansion spatiale et d'un report dans le temps. Un nouveau dispositif institutionnel a consolidé les relations politiques et économiques grâce à des pratiques qui ont permis la production d'un forme novatrice de socio-nature et qui ont reprofilé en paysage industriel la partie Est du front de mer central de Toronto. 